\title{
Melanocyte Protein PMEL
}

National Cancer Institute

\section{Source}

National Cancer Institute. Melanocyte Protein PMEL. NCI Thesaurus. Code C41037.

Melanocyte protein PMEL (661 aa, $70 \mathrm{kDa}$ ) is encoded by the human PMEL gene. This protein plays a role in melanogenesis. 